\title{
关于园林绿化施工技术的探究
}

赖光勋

柳州市河东苗围管理处

DOI:10.18686/bd.v2i9.1661

[摘要] 由于园林绿化施工技术关乎于我国绿色环保发展的要求, 因此, 掌握好园林技术施工的技术要点以及保障措施便 显得至关重要。本研究旨在阐述当前我国园林绿化施工技术方面的阻碍,并探讨对策与保护措施。

[关键词]园林绿化施工技术; 保障措施; 环保

\section{1 园林绿化工程建设发展现状}

园林绿化涉及多个部门的协调工作, 也涉及到多个单 位项目的建设, 但我国目前还缺乏规范园林绿化工程建设 相应的规章制度和法律条款,因此,施工人员在工作中受到 较小的约束力,加之监管部门的管理工作不到位,造成施工 场面较为混乱。同时还存在设计与施工脱节的问题。施工设 计作为园林施工进程中的重要环节, 在整个施工过程中发 挥着重要作用。但由于设计人员不常住施工现场、设计人员 与施工人员交接时间短,因此,即使双方进行了任务交接,也 常使施工人员不能透彻的理解设计人员设计图纸的内容, 所以常常发生施工人员未按设计人员设计意图而凭借自己 的主观想法进行施工的现象。这样使得园林绿化施工的结 果与预期的效果产生巨大差距。我国园林绿化人士良莠不 齐,整体的施工人员素养有待提高。如果只有精美的设计图 纸, 而没有过硬的施工人才队伍, 也不能做出令人满意的成 果。这与很多人认为园林工作人士不需要具备多高的学历、 专业知识和科技含量的错误想法有关。除此之外, 园林绿化 的养护经费时常出现短缺现象。虽然这些年来我国对于园 林绿化的养护费用有了很大的提高, 但距离园林施工的要 求仍然存在着很大差距。对于园林的种植来说仍远远不够。 同时,我国园林工程建设在注重园林建设的同时,却轻视园 林的养护管理。正如谤语所说 “三分种,七分养”,园林的养护 管理是园林的工程建设中重要的一个环节。它是一个长期 的,反复的工作。园林的施工完成不代表园林工程的结束。 实现园林的养护管理,才标志着园林工程建设的结束。如果 没有养护环节,那么,园林工程的建设终将会功亏一管。

\section{2 园林绿化施工设计内容}

2.1 设计的质量管理

质量管理是园林绿化工程项目管理的重中之重。园林 绿化质量管理包括产品质量管理、工序质量管理、工作质量 管理等方面。在施工阶段,要严格控制用料质量,建立质量监 管制度。园林绿化主要材料有石材、砖材、木材、植物、土壤、 管道等, 品种烦多, 质量优劣差异大。在设计时, 需先确定好 材料的品种、规格、肌理; 植物的品种、胸径、分支点等质量 要点,以保证在项目初期就把控好材料的质量。其中对于石 材、木材、绿化植物等主要材料, 必须对其进行项目周期性
地反复校验,对材料在项目实施后的效果、耐久性及质量进 行校核,务必确保选材的质量可靠。

2.2 设计中的成本管理

园林绿化工程的成本主要包括: 征地和拆迁安置补偿 费、勘察设计和前期工程费、主体工程费、公共配套设施建 设费、管理费、贷款利息等。目前, 我国园林绿化工程建设成 本有偏高的倾向, 其中除了用工成本和原材料价格上涨等 因素外,一个重要的原因是园林设计不科学, 在园林设计时 缺乏成本管理理念。就园林绿化工程来说, 主要包括人工费 用、机械费用、材料费用三大项。在设计时,最重要的控制在 于材料的选择和用量上,针对不同类型项目,选择合适的材 料的品种及用量, 可以很好控制工程的造价。植物的品种和 规格的合理选择，也可以很好的控制造价。这样即可以控制 造价又可以最大程度的保证项目效果。

2.3 技术管理

首先要建立园林施工新工艺检验制度。加强对新工艺 检查, 确保新工艺的适用性和安全性, 使其符合园林建设要 求。其次要建立园林新工艺质量监督制度。除了前期的检验 制度之外, 在园林施工过程当中还需要对新工艺的实施过 程进行实时监督, 确保新工艺的施工质量。再次, 要加强政府 的责任, 应该组织建立由政府人员和施工单位负责人共同 组成的园林施工管理组织, 对园林施工中的新工艺的使用 进行全面管理。

\section{3 园林绿化施工技术中需要注意的技术要求}

3.1 表土回填的技术要点分析

土壤是植物生长不可缺少的条件。土壤和肥力对发展 什么样的绿化起着决定性的作用。因此, 只有高质量。只有 这样, 土壤植物才能稳定而迅速地生长。园林植物栽植后进 行土壤回填是十分必要的。为了保持园土圆形结构。因此, 在土壤质量的变化中, 人们通常需要先进行表土处理。需要 适当的回填技术来实现植物生长。但这种技术也存在一些 共性问题,如园林绿化。在施工过程中,地表土必须保持干燥 状态, 以避免表层土壤潮湿时的绿色施工。此外, 我们还必须 更加注意土壤。土壤结构保持良好, 尽量减少大型机械设备 对土壤结构造成的破坏。大型机械和设备挖掘土壤时,我们 可以设法扭转开挖。的行为。对于一些具有团粒结构的土 


\section{浅谈园林绿化施工管理控制}

覃声旺

柳州市河东苗围管理处

DOI:10.18686/bd.v2i9.1663

[摘 要] 随着我国城市化进程的加快以及人们对生活质量的追求逐步提升, 我国的园林绿化工程的数量大大增加, 质量 也不断提高。施工质量管理是园地绿化工程建设的重要一部分。园林绿化的水平和面貌成为影响城市环境质量及城市形象 的重要因素之一。园林绿化具有改善城市环境、净化空气、防减喿音、改善小气候等功能,起着其他城市设施不可替代的作 用。因此,城市园林绿化中新街道的绿化、小区绿地、公共场所的建设, 老城区街道、公园、生活区的改造, 成为大多数中国中 小城市园林部门每年的主要任务之一。本文分析了园林绿化工程施工主要存在的问题, 探讨了加强园林绿化工程施工管理 控制措施。

[关键词] 园林绿化工程;施工质量管理;问题;措施

园林绿化工程的建设不仅能够有效改善城市的面貌和 环境,给城市中的居民创造更加良好的生活环境,还能够提 升城市的品位并改善投资环境，给城市带来更好的发展机 遇。我国的园地绿化工程建设正处于逐步完善和发展的过 程中, 为了提升园林绿地工程的质量水平, 必须将施工质量 管理工作作为发展的重点。

壤,我们必须避免过度碾压。我们必须尽可能地保证土壤颗 粒的完整性,以避免它们造成的破坏物理性质的改变。同时, 根据施工图纸的要求,对地基边坡进行重新设计,使其更好 地起到排水排水的作用。该方法能有效地避免土壤水分问 题,减少施工工作带来的不利影响。

3.2 种植物的栽植与移栽

植物造景是园林绿化建设中的一个重要环节。我们必 须严格按照要求种植,并努力满足植物生长的需要。不可缺 少的物质条件使种植效果更好。在开挖种植洞时,必须按标 准程序种植。根据中心到周边的顺序, 对工人进行挖掘, 同时 确保种植地点的大小与工厂的规格相符。因为种植孔的底 部通常是圆的,所以嘴巴的大小应该保持相等。此外,为了有 效防止植物病变,工作人员需要在在栽种前,对种植穴内的 各种杂物进行清理, 若清理工作不足以达到使其土壤洁净 的效果可考虑更换土壤, 当回填土壤时一定要先将种植土 层捣实, 有利于使植株的根系更好的固定于土壤之中从而 使树木的生长条件更加坚实有保障。

3.3 施工作业中施工队伍的管理与人员安排

由于园林绿化施工工作的工程量巨大, 对于工程的时 间要求较长, 因此, 反季节施工是各地政府绿化工作开展中 常常要面临的问题,为降低投资提高效率,一些绿化工程队 往往选择缩短工期, 这就造成了园林绿化工程的施工质量 降低, 潜在的风险加大。且据调查多数队伍中缺乏合理的领 导与对人员的统筹管理, 以至于许多工程人才的才能并不 能发挥其最大的效用。此外,由于绿化施工工程具有一定的

\section{1 园林绿地工程施工质量管理的重要性}

园林绿地的建设是一个系统全面的过程, 其中涉及很 多环节,包括前期的规划设计、各个环节的施工、施工过程 的监督以及后期的维护等等, 这中间各个环节是否到位都 是影响园林绿化工程质量的重要因素。近年来, 随着城市化 进程的加快以及政府部门对城市绿化的重视, 各种园林绿

观赏价值, 所以对于施工队伍人员对于艺术的赏析能力有 较高的要求。

\section{4 结语}

园林绿化建设在市政建设中占据着十分重要的地位, 且由于环境的整体性，世界各地都有责任担负起保护环境 的义务。园林绿化施工技术作为当前我国有能力也有必要 大力发展的一个方向, 了解其发展中存在的阻碍并研究相 应对策是研究者们需要集中探讨的问题。由于该工程和人 们生活质量密切相关,为了其科学合理化发展, 笔者认为园 林绿化应从景观绿化工程的设计目标出发, 围绕绿化建设 领域制定相应的施工方案。我们还必须确保细节的质量,并 全面动员现有设备和资源的基础上发展园林绿化工程,持 续推动中国环保技术的发展。

\section{[参考文献]}

[1]李云瞻, 关惠,刘冰, 等.园林绿化施工技术要点及保 障措施[J].农业与技术,2015,35(13):132-133.

[2]颜媇.当前城市园林绿化工程施工技术的应用及其 要点探讨[J].中国房地产业,2017,(20):231.

[3] 黄李光. 住宅小区园林绿化工程栽植施工技术分 析一一温州市龙湾城市中心区 $C-14$ 地块景观工程为例 [J].中国园艺文摘,2017,33(12):98-99.

[4]黄付军.关于园林绿化施工与养护管理技术的相关 探讨[J].低碳世界,2017,(28):184.

[5]张莹莹.园林绿化施工与养护管理技术的标准化路 径[J].中国标准化,2017,(16):206-207. 